\title{
KARAKTER PROTEIN ICP11 PADA DNA UDANG VANNAMEI (Penaeus vannamei) YANG TERINFEKSI WHITE SPOT SYNDROME VIRUS (WSSV)
}

\author{
Yuni Kilawati* dan Win Darmanto** \\ *yuniqla@yahoo.com/yuniqla@ub.ac.id. Fisheries and Marine Science Faculty, Brawijaya University \\ ** darmanto@unair.ac.id. Saintech Faculty, Airlangga University
}

\begin{abstract}
The aim of this study was to support policy of government to lessen import and improve export of non migas presented characteristic of genetic of white prawn mains (Penaeus vannamei) so that this product can be yielded in Indonesia with high quality which do not fail with import product. Special goals wishing to be reached at this research is to analyze the genetic characteristic DNA with Polymorphism Chain Reaction (PCR) and primer ICP11. The background of this research was difference among vannamei prawn DNA characteristic that have infected by viruses. With experimental methods ten healthy post larva of white prawn cultured in aquarium and invected by WSSV virus in $1 \mathrm{ml} / 10 \mathrm{l}$ marine water dossage with three time replication during 7 days in culture. To know these infection, the sample were analyze with specific primer ICP11.
\end{abstract}

Key words: DNA; ICP11; PCR; white shrimp (Penaeus vannamei)

\section{PENGANTAR}

Pemijahan berulang yang dilakukan pada SPF udang vannamei di Indonesia menghasilkan keturunan yang memiliki kekebalan tidak sama, hal ini disebabkan oleh banyak variabel di antaranya asal-usul induk, keturunan keberapa, pemantauan mutu genetik dan lingkungan. Melihat kenyataan ini diduga SPF udang juga memiliki ketahanan yang berbeda terhadap serangan penyakit WSSV. White Spot Syndrome Virus (WSSV) adalah salah satu jenis penyakit yang menyerang spesies udang yang dibudidayakan dan jenis crustacea yang lainnya. Pada tambak udang, virus ini dapat mengakibatkan total kematian $100 \%$ pada 2 sampai 10 hari penyerangan (Wang et al., 2007).

Pada sel organ udang yang terserang WSSV, virus ini ditemukan di sitoplasma (Chen et al., 2002). Mekanisme penyerangan WSSV ke tubuh udang awalnya bersifat intrasitoplasmik, yaitu masuk ke dalam sel inang kemudian pada tingkat serangan yang lebih tinggi DNA virus masuk ke dalam DNA inang dan mengambil alih proses transkripsi dan translasi sesuai proses dalam DNA virus.

Replikasi WSSV bisa terjadi pada beberapa bagian sel dengan nukleus sebagai letak utama virus berplikasi (Wang et al., 2000). Akan tetapi pertumbuhan dan kematangan partikel-partikel virus setelah diamati berkali-kali, berada di dalam sitoplasma dari folikel sel (Lo et al., 1997). Pada penelitian yang dilakukan Wang (2004) bahwa hasil dari imunofluoresen assay dan electron microscopy menunjukkan positif VP28 pada sitoplasma sel yang terinfeksi WSSV, sinyal positif ini kemungkinan disebabkan tidak hanya oleh protein VP28 bebas tapi juga oleh VP28 yang terdapat pada virion. Hal ini konsisten dengan ide bahwa replikasi dan morfogenesis DNA WSSV kemungkinan terjadi di sitoplasma sel udang yang terinfeksi.

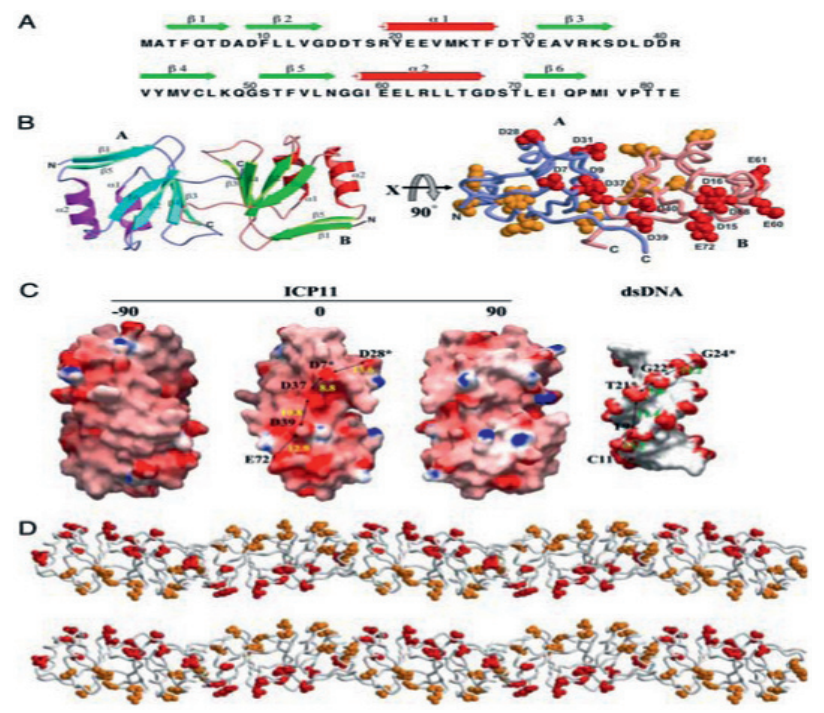

Gambar 1. Distribusi muatan negatif ICP11 yang menyerupai bentuk B DNA helik. (A) Elemen struktur sekunder sekuen asam amino: garis bawah hijau dan tabung merah: $\beta$-strand dan $\alpha$-heliks, (B) Pita dimer ICP11 (kiri) Strands dan heliks monomer A: biru dan merah, (C) Dimer ICP11 dan dsDNA. Kode pewarnaan GRASP, merah - biru: potensial elektrostatik $-15 \mathrm{k}_{\mathrm{B}} \mathrm{T}$, sampai $+15 \mathrm{k}_{\mathrm{B}} \mathrm{T}$, (D) Persebaran muatan negatif asam amino ICP11 (Wang et al., 2008). 
Pada level transkripsi dan translasi yang terjadi pada sel inang yang telah terserang virus WSSV terekspresi suatu protein. Protein ini bersifat nonstruktural dan menurut Wang et al. (2007). Protein ini dinamakan ICP11. Gambaran bentuk ICP11 sesuai penelitian yang dilakukan oleh Wang et al., 2008 disajikan pada Gambar 1.

ICP11 adalah protein nonstruktural yang terbanyak diekspresikan oleh gen WSSV, yang mana diduga kuat sangat berperan pada infeksi WSSV, namun sampai sekarang fungsinya diabaikan untuk diamati. Pada penelitian yang dilakukan baru-baru ini oleh Wang et al. (2008) menghasilkan ICP11 berperan seperti sebuah DNA. Dalam kristal ICPII dibentuk oleh sebuah polimer dari dimer dengan 2 baris titik yang bermuatan negatif yang diasumsikan adalah susunan duplek dari kelompok phospat pada DNA. ICP11 mengikat pada histon protein inang, berfungsi melindungi DNA dari ikatannya terhadap histon protein $\mathrm{H} 2 \mathrm{~A}, \mathrm{H} 2 \mathrm{~B}, \mathrm{H} 3$ dan $\mathrm{H} 2 \mathrm{~A}$. $\mathrm{x}$. Pada hemocyte udang yang terinfeksi WSSV, ICP11 terletak bersama $\mathrm{H} 3$ dan diaktifkan oleh H2A.x., untuk lebih jelasnya ditunjukkan pada Gambar 2 berikut ini.

\section{BAHAN DAN CARA KERJA}

Bahan yang dipakai pada penelitian ini adalah: Stok primer, Aquades, 10× $\mathrm{BD}$ Advantage 2 PCR-Buffer,
dNTP $(10 \mathrm{mM}), 50 \times \mathrm{BD}$ Advantage $\mathrm{TM}^{\mathrm{T}} 2$ polymerase mix, Agarose gel, TAE, ETBR, Loading buffer. Peralatan yang dipakai adalah: Mesin PCR, vortex, refrigerator, centrifuge, microwave, Elektroforesis.

Sampel udang diuji tantang dengan isolat WSSV dengan dosis $0,1 \mathrm{ppm}$ pada lingkungan yang terkontrol selama 7 hari. Sampel yang telah diuji tantang dengan WSSV menghasilkan 3 kelompok yaitu udang rentan terhadap penyakit ditandai dengan kematian dan yang tahan terhadap penyakit atau survive sampai akhir masa pengamatan serta yang tidak diinfeksi WSSV. Ketiga kelompok ini kemudian dianalisis PCR dengan primer spesifik, yaitu ICP11. Proses amplifikasi gen ICP11 udang vannamei Indonesia yang tahan dan yang rentan terhadap WSSV serta yang tidak diinfeksi WSSV, dilakukan dengan cara menambahkan primer ICP11_F dan ICP11_R pada masing-masing tabung yang telah berisi sampel, dan dimasukkan dalam thermocycler sebanyak 34 siklus.

\section{HASIL}

Hasil desain primer spesifik untuk mengetahui hasil penginfeksian dalam DNA udang putih disajikan pada Tabel 1.

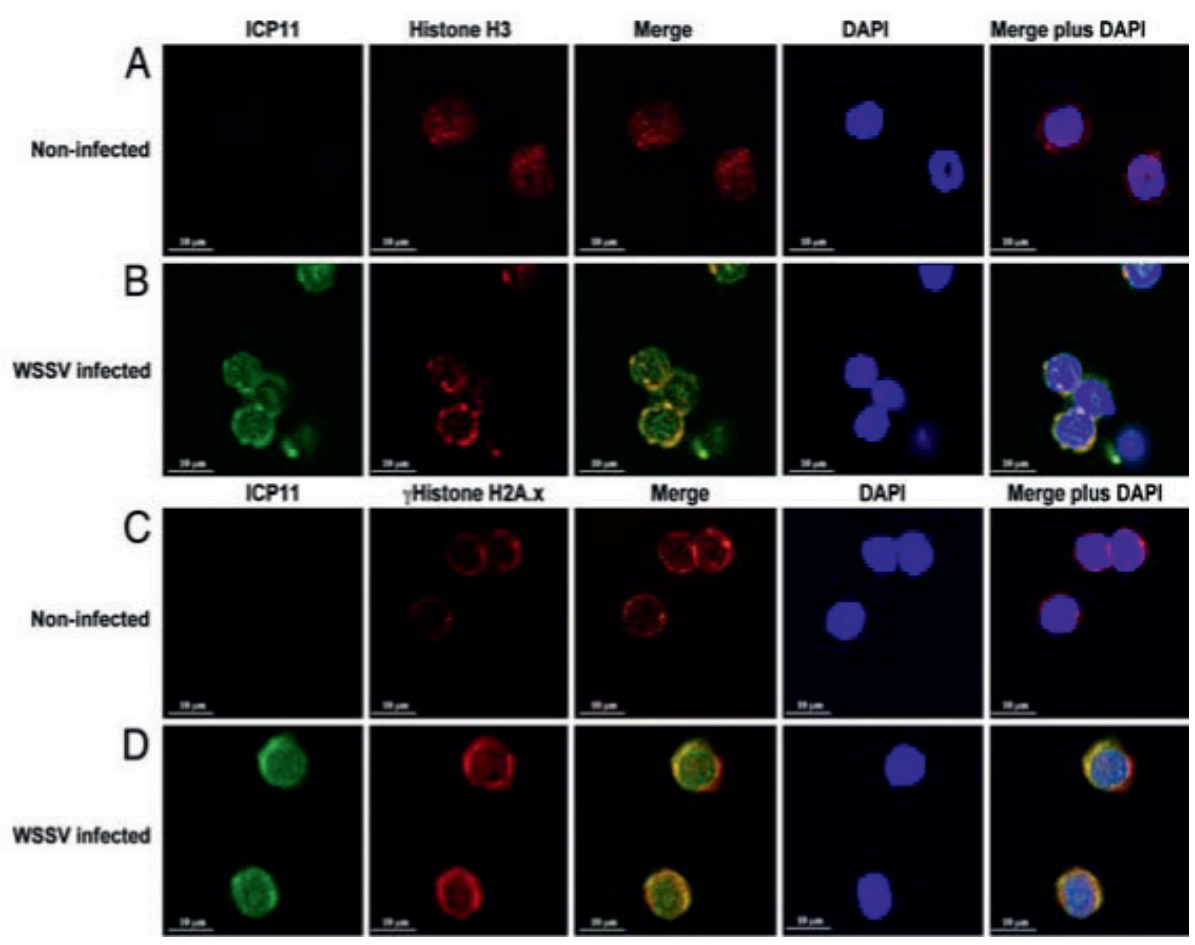

Gambar 2. ICP11 yang terletak pada histone $\mathrm{H} 3$ dan histone $\mathrm{H} 2 \mathrm{~A}$. $\mathrm{x}$ in vivo. Kontrol dan hemocyte udang terinfeksi WSSV yang diawetkan dengan paraformaldehyde (72 hpi), pewrana untuk ICP11 (FITC, green) dan untuk histone H3 (A dan B) dengan TRITC (merah) dan $\gamma$ histone H2A.x (C dan D). area hijau menunjukkan letak histone protein dan ICP11 yang terletak pada area yang sama (Wang et al., 2007). 
Tabel 1. Diskripsi primer ICP11

\begin{tabular}{lc}
\hline $\begin{array}{l}\text { a. ICP11 for forward (Wsv230_ } \\
\text { 19F22) }\end{array}$ & $\begin{array}{c}\text { b. ICP11 for reverse } \\
\text { (Wsv230_202R24) }\end{array}$ \\
\hline$\checkmark 5^{\prime}$ GAC GCC GAT TTC TTG & $\checkmark 5^{\prime}$ GGG TTG AAT CTC \\
CTG GTG G 3' & CAG CGT TGA ATC 3' \\
$\checkmark$ A $=2, \mathrm{G}=8, \mathrm{C}=5, \mathrm{~T}=7$ & $\checkmark$ A $=5, \mathrm{G}=7, \mathrm{C}=5, \mathrm{~T}=7$ \\
$\checkmark$ G-C contain $59 \%$ & $\checkmark$ G-C contain $50 \%$ \\
$\checkmark$ Melting Point $70^{\circ} \mathrm{C}$ & $\checkmark$ Melting Point $72^{\circ} \mathrm{C}$ \\
$\checkmark$ Konsentration in $1 \mathrm{ml}: 62 \mu \mathrm{M}$, & $\checkmark$ Konsentration in $1 \mathrm{ml}:$ \\
$\checkmark$ For 50 molar $(50 \mathrm{pmol} / \mu \mathrm{l})$ & $45 \mu \mathrm{M}$, \\
dilution in aquades $1249 \mu \mathrm{l}$ & $\checkmark$ For 50 molar $(50 \mathrm{pmol} / \mu \mathrm{l})$ \\
$\checkmark$ OD 14.3 & dilution in aquades $891 \mu \mathrm{ll}$ \\
& $\checkmark$ OD 11.7 \\
\hline
\end{tabular}

Hasil amplifikasi gen ICP11 ditunjukkan pada Gambar 3.

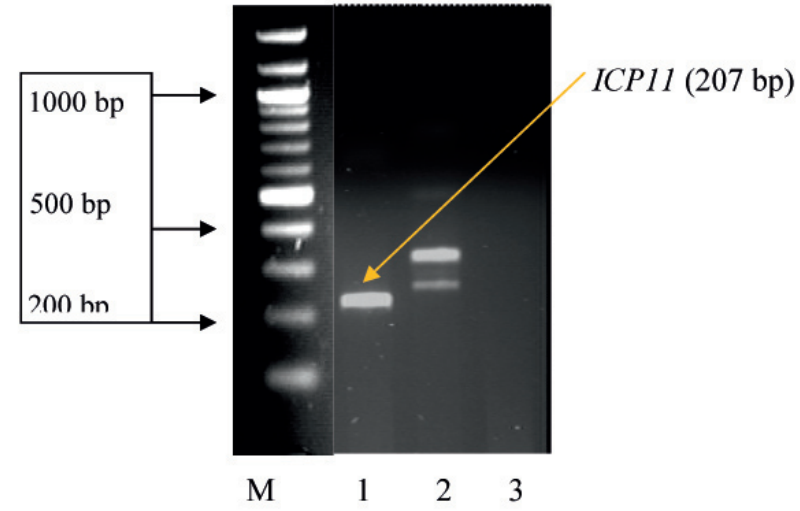

Gambar 3. Pola pita hasil amplifikasi ICP11 pada udang vannamei Indonesia yang rentan dan tahan WSSV (M: DNA ladder $100 \mathrm{bp}$, 1: udang vannamei yang rentan terhadap WSSV, 2: udang vannamei yang tahan terhadap WSSV dan 3: udang yang tidak diinfeksi WSSV)

Pada gambar 3, ditunjukkan bahwa kuantitas ICP11 dari udang vannamei yang telah diinfeksi WSSV baik yang tahan atau yang rentan cukup baik, karena pola pita dapat dilihat dengan jelas pada gel agarose. Pada jalur 1 adalah sampel udang vannamei yang rentan terhadap WSSV, ICP11 berhasil diamplifikasi pada $207 \mathrm{bp}$. Pada jalur 2 sampel

Tabel 2. Amplifikasi gen ICP11 pada udang vannamei Indonesia yang rentan dan tahan WSSV

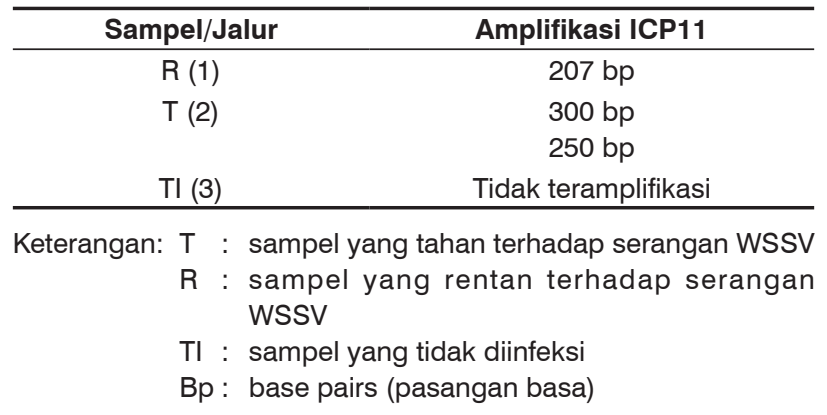

udang vannamei yang tahan terhadap WSSV, ICP11 berhasil diamplifikasi pada dua tempat yaitu 300 dengan pita yang lebih jelas dan pada 250 bp dengan pita yang lebih samar. Pada jalur 3 adalah sampel udang yang tidak diinfeksi WSSV, dan tidak terjadi amplifikasi ICP11.

Untuk lebih memperjelas rekapitulasi hasil dokumentasi gel elektroforesis dari pola pita yang dihasilkan dari amplifikasi ICPI1 pada udang yang rentan, tahan dan tidak diinfeksi WSSV disajikan pada Tabel 2.

\section{PEMBAHASAN}

Gen ICP11 dipilih berdasarkan penelitian yang dilakukan oleh Wang et al.,2008), bahwa ICP11 adalah protein non struktural yang disandi oleh gen ICP11 yang diduga kuat sangat berperan pada infeksi WSSV.

ICP11 adalah protein non struktural yang dominan diekspresikan oleh gen WSSV, yang mana diduga kuat sangat berperan pada infeksi WSSV, namun sampai sekarang fungsinya diabaikan untuk diamati. Pada penelitian yang dilakukan baru-baru ini oleh Wang et al. (2008), menghasilkan ICP11 berperan seperti sebuah DNA. Dalam kristal ICP11 dibentuk oleh sebuah polimer dari dimer dengan 2 baris titik yang bermuatan negatif yang diasumsikan adalah susunan duplek dari kelompok phospat pada DNA.

Sampel DNA dibagi menjadi 3, yang pertama yaitu udang vannamei yang diuji tantang dan terinfeksi dengan indikasi perubahan morfologi, tingkah laku dan mengalami kematian, yang kedua adalah yang diuji tantang WSSV tetap survive atau tidak terinfeksi hingga akhir perlakuan dan yang ketiga atau kontrol adalah udang vannamei yang sehat atau tidak diinfeksi WSSV.

Hasil amplifikasi gen ICP11 antara kelompok sampel 1, kelompok sampel 2 serta kelompok 3, memberikan hasil yang berbeda. Amplifikasi gen ICP11 pada udang yang rentan terhadap WSSV menghasilkan pita sebesar 207 bp, sedangkan pada udang yang tahan terhadap WSSV adalah sebesar 300 bp dan $250 \mathrm{bp}$, serta pada udang yang tidak diinfeksi WSSV tidak menghasilkan pita.

Pada kelompok pertama, yaitu udang vannamei yang rentan terhadap serangan WSSV, ICP11 teramplifikasi dengan kuantitas paling banyak dan pada posisi yang tepat hal ini disebabkan DNA virus yang telah menginsersi secara sempurna pada DNA sel inang sehingga udang tidak mampu bertahan dan menyebabkan kematian. Hasil penelitian menunjukkan bahwa secara biologis ICP11 memiliki peran penting dalam kematian sel yang terserang WSSV, dengan beberapa kemungkinan mekanisme yang terjadi. Mekanisme yang pertama adalah bahwa 
ICP11 langsung menyebabkan gangguan nukleosom, sehingga menyebabkan kematian sel. Kemungkinan lain adalah bahwa ICP11 dapat menyebabkan kematian sel melalui mekanisme yang tidak langsung, yaitu dengan mengikat histone di sitoplasma. ICP11 dapat mengganggu mekanisme dengan mencegah histone terikat ke inti, sehingga terjadi destabilisasi nukleosom, yang memiliki peran sangat penting bagi pengaturan epigenetik ekspresi gen dan konsekuensi adalah terjadinya kematian sel.

Pada kelompok kedua yaitu udang vannamei yang tahan terhadap serangan WSSV, ICP11 teramplifikasi pada 2 pita dengan kuantitas yang berbeda. Pada 300 bp diperoleh pita dengan kuantitas yang lebih banyak sedangkan pada 250 bp lebih samar. Amplifikasi yang terjadi pada 2 pita ini menunjukkan adanya polimorfisme yang bisa terjadi karena adanya kontrol gen. Kontrol gen pada eukariot dilakukan dengan cara langsung menanggapi perubahan lingkungan dengan proses fisiologis. Apabila terjadi perubahan lingkungan secara ekstrim yang tidak sesuai bagi kebutuhan hidup secara normal organisme tersebut, maka proses fisiologis akan menyesuaikan sebagai hasil kerja dari kontrol gen. Pada kondisi lingkungan yang tidak sesuai dan terjadi terus-menerus akan mengakibatkan perubahan pada level gen sebagai respon dan usaha untuk beradaptasi.

Pada kelompok tiga yaitu kontrol tidak dijumpai pita atau ICP11 tidak teramplifikasi karena berisi DNA sampel udang yang sehat sedangkan ICP11 adalah berasal dari gen virus WSSV sehingga bisa dipastikan pada udang vannamei yang tidak diinfeksi WSSV maka tidak terdapat virus WSSV di dalam selnya. Hasil yang diperoleh menunjukkan bahwa primer ICP11 dapat dipakai sebagai marker untuk mendeteksi ketahanan udang vannamei di Indonesia terhadap serangan WSSV karena memberikan hasil pita yang berbeda antara udang yang tahan dan rentan terhadap infeksi WSSV serta udang yang sehat sebagai kontrol.

Ketebalan atau kuantitas pita yang berbeda, yaitu pada udang yang rentan memiliki ketebalan yang lebih dibandingkan dengan yang tahan menunjukkan bahwa pada udang yang rentan ICPI1 yang terekspresi lebih besar dibandingkan pada udang yang tahan terhadap WSSV. Didukung keterangan Wang, et al. (2008), bahwa kelimpahan ICP11 disel inang menghalangi inti sel protein histone, yang mengakibatkan DNA dalam sel inang rentan mengalami kerusakan, dan akhirnya mengarah ke gangguan mesin genetik di dalam nukleus.
Kemunculan jumlah pita yang tidak sama diduga karena proses terjadinya infeksi yang berlangsung dalam sel inang menimbulkan ekspresi yang berbeda pula. Hal ini sering ditemui pada penampakan pita yang dihasilkan oleh beberapa kit produksi industri. Pita yang dihasilkan pada kit tersebut beragam mulai dari serangan rendah sampai tinggi.

Dari penelitian ini dapat disimpulkan bahwa ekspresi gen ICP11 udang vannamei Indonesia yang tahan dan yang rentan terhadapWSSV adalah berbeda, pada udang yang tahan teramplifikasi pada $207 \mathrm{bp}$ sedangkan yang rentan teramplifikasi pada $300 \mathrm{bp}$ dan $250 \mathrm{bp}$. Primer ICP11 dapat digunakan sebagai primer spesifik untuk mendeteksi penyakit WSSV pada udang vannamei.

\section{KEPUSTAKAAN}

Chen LL, Leu JH, Huang CJ, Chou CM, Chen SM,Wang CH, Lo CF, dan Kou GH, 2002. Identification of a Nucleocapsid Protein (VP35) Gene of Shrimp White Spot Syndrome Virus and Characterization of The Motif Important for Targeting VP35 to The Nuclei of Transfected Insect Cells. Virology 293: 44-53.

Lo CF, Ho CH, Chen CH, Liu KF, Chiu YL, Yeh PY, et al. 1997. Detection and Tissue Tropism of White Spot Syndrome Baculovirus (WSBV) in Captured Brooders of Penaeus Monodon with a Special Emphasis on Reproductive Organs. Dis Aquat Organ 1997, 30: 53-72.

Wang Q, Poulous BT and Lightner DV, 2000. Protein Analysis of Geographic Isolates of Shrimp White Spot Syndrome Virus. Arch Virol, 145: 263-274.

Wang Han-Ching, Chang Yun-Shiang, Kou Guang-Hsiung and Lo Chu-Fang, 2004. White Spot Syndrome Virus: Molecular Characterization of a Major Structural Protein in a Baculovirus Expression System and Shrimp Hemocytes. Mar. Biotechnol 6: S95-S99.

Wang HC, Hao-Ching Wang, Guang-Hsiung Kou, Chu-Fang Lo, dan Wei-Pang Huang, 2007. Identification of Icp 11, The Most Highly Expressed Gene of Shrimp White Spot Syndrome Virus (WSSV). Diseases of Aquatic Organisms 74: $179-89$.

Wang, Hao-Ching, Wang Han Ching, Ko Tzu Ping, Lee YuMay, Leu Jian-Horng, Ho Chun-Han, Huang Wei-Pang, Lo Chu-Fang and Andrew Wang HJ, 2008. White spot syndrome virus protein ICP11: A histone-binding DNA mimic that disruptsnucleosome assembly. PNAS, 105(52): 20768-83.

Reviewer: Prof. Dr. Ir. Hari Soeprapto 